Наносистели, нанолатеріали, нанотехнології Nanosistemi, Nanomateriali, Nanotehnologii 2020, т. 18, № 1, cc. $1-14$ (c) 2020 IMФ (Інститут металофізики ім. Г. В. Курдюмова НАН України) Надруковано в Україні. Фотокопіювання дозволено тільки відповідно до ліцензі

PACS numbers: 61.48.Gh, 73.30.+y, 81.05.U-, 81.05.ue, 82.47.Uv, 84.32.Tt

\title{
Graphene vs Activated Carbon in Supercapacitors
}

\author{
S. O. Zelinskyi, N. G. Stryzhakova, and Yu. A. Maletin \\ Institute for Sorption and Problems of Endoecology, N.A.S. of Ukraine, \\ 13, General Naumov Str., \\ UA-03164 Kyiv, Ukraine
}

Four graphene materials and four activated carbons from various producers as well as carbon black from Cabot company and compositions of all these materials are tested as electrodes of electrochemical double layer capacitors (EDLC). As revealed, the specific capacitance of graphene-based electrodes and capacitance retention with an increase in current are inferior to the values, which can be achieved with the best activated carbons specially developed for the EDLC application. Fairly good correlation between the surface area and the electrostatic capacitance of electrode materials is revealed resulting in the capacitance of electric double layer of graphene, graphenecontaining and activated carbon materials tested in this work to be close to $0.052 \mathrm{~F} / \mathrm{m}^{2}$.

3 чотирьох типів графенових матеріялів і чотирьох на основі активованого вугілля, наданих різними виробниками, а також сажі компанії Cabot та їхніх композицій виготовлено та випробувано електроди в електрохемічних конденсаторах подвійного електричного шару (EDLC). Встановлено, що питома ємність електрод на графеновій основі та стабільність ємности зі збільшенням струму поступаються значенням, які можна досягти із найліпшим активованим вугіллям, спеціяльно розробленим для застосування EDLC. Було виявлено достатньо хорошу кореляцію між площею поверхні й електростатичною ємністю електродних матеріялів. Показано, що ємність електричного подвійного шару з графену, графеновмісних матеріялів і активованого вугілля, що вивчалися в даній роботі, становить $0,052 \Phi / \mathrm{M}^{2}$.

Четыре типа материалов на основе графена и четыре на основе активированных углей, полученных от различных производителей, а также специальная сажа компании Cabot и композиции на основе всех этих материалов испытаны в качестве электродов конденсаторов двойного электрического слоя (EDLC). Найдено, что удельная электростатическая ёмкость и поддержание ёмкости с увеличением тока при использовании графеновых электродов проигрывают значениям, которые можно достичь при исполь- 
зовании лучших образцов активированных углей, специально разработанных для применений в EDLC. Получена достаточно хорошая корреляция между удельной поверхностью электродных материалов и их электростатической ёмкостью, что даёт для графенов, графенсодержащих материалов и активированных углей, которые были изучены в данной рабо-

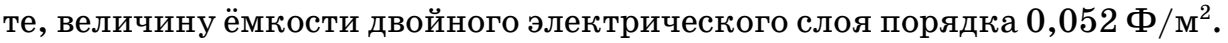

Key words: supercapacitor (ionistor), graphene materials, activated carbon, energy storage.

Ключові слова: суперконденсатор (іоністор), графенові матеріяли, активоване вугілля, енергозбереження.

Ключевые слова: суперконденсатор (ионистор), графеновый материал, активированный уголь, энергосбережение.

(Received 24 September, 2019)

\section{INTRODUCTION}

Since the Nobel Prize award in 2010, the scientific community is being interested in graphene [1] and, in particular, in its various applications [2]. In this work, we will focus on possible applications of graphene in energy storage technologies [3-5], namely, in electrodes of electrochemical double layer capacitors (EDLC) also known as supercapacitors or ultracapacitors. In today's EDLC technology, various activated (nanoporous) carbons are used as major electrode components, and below, it will be verified whether graphene can successfully replace them or can it be used as a complementary material to improve the electrode characteristics.

EDLC, which appeared as commercial energy storage devices about 40 years ago, now enter more and more market niches like hybrid transport, wind turbines, consumer electronics, etc. [6, 7]. Though EDLC can store much less energy than batteries, they have an obvious advantage over all types of batteries by their power density and efficiency, quick charge, number of charge-discharge cycles and operating temperature range. This performance is due to the combination of huge surface area of EDLC electrodes and very low internal resistance of the EDLC electrochemical system [8]. The latter, in its turn, results from the absence of any charge or mass transfer through the electrode-electrolyte interface, which is a common process in batteries. In EDLC, the energy stores due to charge separation at this interface, and the speed of the charge separation process is limited by the electrolyte diffusion only [9, 10]. So, bearing in mind the very high surface area and conductivity of graphene (of the order of $2630 \mathrm{~m}^{2} / \mathrm{g}$ and $2 \cdot 10^{5} \mathrm{~S} / \mathrm{m}$, respectively 
$[11,12])$, the material looks promising to provide large capacitance and low internal resistance of EDLC if being used as the major electrode component or, at least, as a complementary one [13].

In this work, we will focus on the results of electrochemical studies of EDLC comprising graphene as an active electrode material in both electrodes, though there are also a good number of works, wherein graphene is used to form the anode material in various types of $\mathrm{Li}[14,15]$ or $\mathrm{Na}$ [16] batteries. Methods for obtaining graphene will not be discussed either, though in many cases the material performance depends on the synthetic method.

\section{EXPERIMENTAL}

The following nanostructured carbons have been studied:

- G250H graphene from SinoCarbon Innovation \& Investment

Co., Ltd. (China), denoted below as GH;

- $x \mathrm{GnPC750}$ graphene from XG Science, Inc. (USA), denoted below as $x \mathrm{Gn}$;

- C2087/rGOB006/Pw reduced graphene oxide from Graphenea (Spain), denoted below as $r \mathrm{GO}$;

- a sample of mechanically obtained graphene powder from Yunasko laboratory (Ukraine), denoted below as GY;

- M120 carbon black from Cabot Corporation (USA), denoted below as $\mathrm{CB}$;

- YP50F activated carbon from Kuraray Chemical Co., Ltd (Japan), denoted below as Y5;

- YP80F activated carbon from Kuraray Chemical Co., Ltd (Japan), denoted below as Y8;

- HDLC 20B STUW activated carbon from Haycarb PLC (Sri Lanka), denoted below as HC;

- EliteC activated carbon from Calgon Carbon Corporation, denoted below as EC.

Surface area and pore size distribution of all the materials were studied with the use of isotherms of nitrogen gas sorption-desorption at $77 \mathrm{~K}$ that were obtained with NOVA 2200 analyser (Quantachrome, USA). The carbon specimens were kept in vacuum of $1 \cdot 10^{-4}$ Torr at $180^{\circ} \mathrm{C}$ for 4 hours before the measurements. The DFT method was used to study the micro- and mesoporous structure, and BET method was also involved for comparison purposes. Separately, the sorption of $\mathrm{CCl}_{4}$ vapour at room temperature was measured to see the share of pores larger than $0.63 \mathrm{~nm}$ as was recommended in [17, 18].

Electrochemical characteristics of graphenes, activated carbons, carbon black and their mixtures were studied in EDLC prototypes with the use of Arbin SCTS5-25 test bench for capacitance, internal resistance and self-discharge measurements, or Voltalab-80 PGZ 402 for 
impedance and cyclic voltammetry measurements. Capacitance, internal resistance and self-discharge values were evaluated according to IEC62391 standard [19] followed by recalculating the capacitance values per unit mass or volume of the prototype active electrodes and internal resistance per 1 sq.cm of the electrode visible area.

Active electrodes were manufactured by roller pressing the mixture of the corresponding carbon powder (graphene and/or activated carbon) with PTFE binder. The binder content was $7 \%$ of the total electrode mass. The only exceptions were $\mathrm{CB}$ electrodes that were manufactured by coating method with PVDF binder since the roller pressing could not provide the proper mechanical strength. In most cases, the electrodes of $100 \mu \mathrm{m}$ thick were manufactured except the $x \mathrm{Gn}$ and $\mathrm{CB}$ materials; in these cases, we could prepare the electrodes of $200 \mu \mathrm{m}$ thick $(x \mathrm{Gn})$ or $40 \mu \mathrm{m}$ thick (CB) only. The electrode tapes thus made were laminated onto the aluminium foil that was used as the current collector. The foil was preliminarily treated by electric-spark deposition of graphite [20] and covered by a thin layer of carbon black/PVDF mixture to improve the conductivity and adhesion between the active electrode layer and current collector. Electrode footprint on the collector was $30 \times 50 \mathrm{~mm}$, and electrodes thus manufactured were dried in vacuum at $220^{\circ} \mathrm{C}$ (except CB-based ones, which were dried at $150^{\circ} \mathrm{C}$ ) for 12 hours followed by fabricating the EDLC prototypes in a dry glove box. Each EDLC prototype comprised a pair of electrodes, positive and negative, interleaved with a porous cellulosic film (separator, TF4530 produced by Nippon Kodoshi), impregnated with organic electrolyte (1M $\mathrm{Et}_{4} \mathrm{NBF}_{4}$ in acetonitrile, produced by BASF) and hermetically sealed in a laminated aluminium shell. At least, three prototypes were fabricated with each type of electrodes.

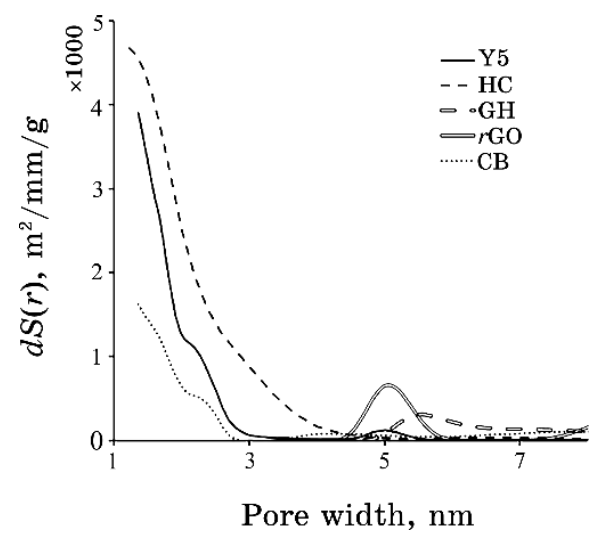

Fig. 1. Increments of specific surface area $v s$ pore width for some selected carbons (DFT study). 


\section{RESULTS AND DISCUSSION}

\subsection{Porosity of carbon materials and electrode properties}

Figure 1 illustrates the differential surface area $v s$. pore size in some of the tested materials selected for comparison purposes. We have chosen the pore width exceeding $1 \mathrm{~nm}$, since accordingly to our data, these pores are of major interest for EDLC with organic electrolytes and, in particular, for EDLC application under high load conditions. As can be seen from Fig. 1, the Y5, Y8, HC and EC activated carbons (all are used in the EDLC industry) have the main porosity at the boundary between micro- and mesopores, namely, of about 1-3 nm with some minor contribution from larger pores. Graphene materials have more significant contribution from mesoporosity. This can also be seen in more detail from Table 1, wherein the data obtained with the use of BET or DFT methods are listed. Some differences between the surface values may be accounted for different calculation techniques used in BET and DFT models to treat the sorption-desorption curves [21]. The general result is that graphene materials have larger medium pore width (except the $x \mathrm{Gn}$ sample) and obviously less total surface area than activated carbons or CB. In our further discussion, we will refer to DFT results since they correlate with capacitance measurements much better than BET data, as was also discussed in detail in [22].

All the materials and their combinations were used to fabricate the EDLC electrodes as described in Sec. 3.2, and the electrode compositions and characteristics are listed in Table 2. The GH graphene could not be used as a single active material because of the poor mechanical strength of GH-based electrodes (even at increased binder content)

TABLE 1. Characteristics of pore structure of carbon materials under study.

\begin{tabular}{c|c|c|c}
\hline \multirow{2}{*}{$\begin{array}{c}\text { Carbon } \\
\text { powder }\end{array}$} & BET data & \multicolumn{2}{|c}{ DFT data } \\
\cline { 2 - 4 } & $\begin{array}{c}\text { Specific surface } \\
\text { area }, \mathrm{m}^{2} / \mathrm{g}\end{array}$ & $\begin{array}{c}\text { Specific surface } \\
\text { area, } \mathrm{m}^{2} / \mathrm{g}\end{array}$ & $\begin{array}{c}\text { Medium } \\
\text { pore width, } \mathrm{nm}\end{array}$ \\
\hline Y5 & 2013 & 2174 & 1.4 \\
Y8 & 2505 & 2418 & 2.5 \\
HC & 1733 & 2144 & 1.6 \\
EC & 1755 & 2040 & 1.4 \\
GH & 695 & 805 & 5.6 \\
$x$ Gn & 826 & 985 & 1.4 \\
rGO & 446 & 446 & 5.2 \\
GY & 1350 & 1440 & 5.1 \\
CB & 1583 & 1965 & 1.4 \\
\hline
\end{tabular}


TABLE 2. Electrode composition and density.

\begin{tabular}{|c|c|c|c|c|c|}
\hline $\begin{array}{l}\text { Electrode } \\
\text { material }\end{array}$ & No. & $\begin{array}{c}\text { Electrode } \\
\text { composition }^{1}\end{array}$ & $\begin{array}{c}\text { Activated } \\
\text { carbon, \% wt }\end{array}$ & $\begin{array}{c}\text { Graphene } \\
\text { or CB, \% wt. }\end{array}$ & $\begin{array}{c}\text { Electrode } \\
\text { density, g/cc }\end{array}$ \\
\hline \multirow{4}{*}{$\begin{array}{l}\text { Activated } \\
\text { carbon }\end{array}$} & 1 & 1:0[Y5:0] & Y5, 46.5 & - & 0.67 \\
\hline & 2 & 1:0[Y8:0] & Y8, 93 & - & 0.50 \\
\hline & 3 & $1: 0[\mathrm{HC}: 0]$ & HC, 93 & - & 0.62 \\
\hline & 4 & $1: 0[\mathrm{EC}: 0]$ & EC, 93 & - & 0.65 \\
\hline \multirow{3}{*}{ Graphene } & 5 & $0: 1[0: x \mathrm{Gn}]^{2}$ & - & $x \mathrm{Gn}, 93$ & 0.73 \\
\hline & 6 & $0: 1[0: r G O]$ & - & $r \mathrm{GO}, 93$ & 0.64 \\
\hline & 7 & $0: 1[0: G Y]$ & - & GY, 93 & 0.71 \\
\hline Carbon black & 8 & $0: 1[0: \mathrm{CB}]^{3}$ & - & $\mathrm{CB}, 85$ & 0.68 \\
\hline \multirow{7}{*}{ 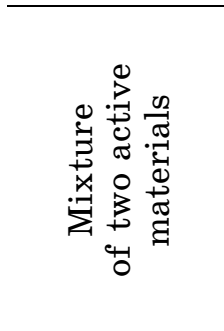 } & 9 & 9:1[Y8:GH] & Y8, 83 & $\mathrm{GH}, 10$ & 0.48 \\
\hline & 10 & 1:1[Y8:GH] & Y8, 46.5 & $\mathrm{GH}, 46.5$ & 0.36 \\
\hline & 11 & $9: 1[\mathrm{HC}: \mathrm{GH}]$ & $\mathrm{HC}, 83$ & GH, 10 & 0.56 \\
\hline & 12 & $9: 1[\mathrm{HC}: x \mathrm{Gn}]$ & $\mathrm{HC}, 83$ & $x \mathrm{Gn}, 10$ & 0.63 \\
\hline & 13 & $1: 1[\mathrm{HC}: x \mathrm{Gn}]$ & $\mathrm{HC}, 46.5$ & $x \mathrm{Gn}, 46.5$ & 0.72 \\
\hline & 14 & 1:1[Y8:rGO] & Y8, 46.5 & $r \mathrm{GO}, 46.5$ & 0.60 \\
\hline & 15 & 1:1[Y8:CB] & Y8, 46.5 & $\mathrm{CB}, 46.5$ & 0.62 \\
\hline
\end{tabular}

Note: ${ }^{1}$ Electrode composition as $9: 1[\mathrm{HC}: \mathrm{GH}]$ denotes the ratio between activated carbon and another active electrode component, e.g., here the ratio between HC and GH is 9:1 by mass. ${ }^{2}$ These electrodes were manufactured of $200 \mu \mathrm{m}$ thick. ${ }^{3}$ These electrodes were manufactured of $40 \mu \mathrm{m}$ thick with $15 \%$ wt. of PVDF binder.

and, therefore, it was used in combination with activated carbon. In our opinion, it may be accounted for the significant heterogeneity of the GH powder and the tendency to aggregation of two-dimensional graphene units. From Table 2, it can also be seen that adding this powder to the electrode composition reduces the electrode density.

\subsection{Electrochemical characteristics of EDLC prototypes}

Capacitance, internal resistance, their product ( $R C$ - or time-constant, in $s$ ) and a decrease in capacitance with an increase in current $(-d C / d I$ slope) were measured for all the EDLC prototypes manufactured as described in Sec. 2. Capacitance and internal resistance were determined by charging-discharging the prototypes with a constant current value within the voltage range between the rated (upper) voltage, $U_{\max }$, and half of this voltage, $U_{\min }=0.5 U_{\max }$ (e.g., see a typical charge-discharge curve in Fig. 2). The internal resistance, $R_{D C}$ (in $\Omega$ ), was evaluated from the voltage drop (or $I R$-drop) when switching the discharge current, $I$, according to Eq. (1): 


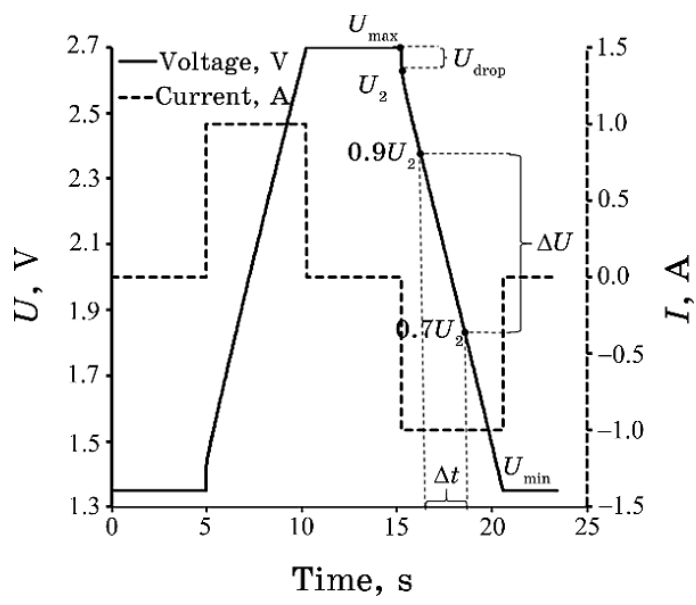

Fig. 2. Typical charge-discharge curves used to evaluate the characteristics of EDLC prototypes (here with Y8 electrodes).

$$
R_{D C}=\frac{U_{\max }-U_{2}}{I},
$$

The capacitance $C$ was evaluated from the discharge curve according to Eq. (2):

$$
C=\frac{I \Delta t}{\Delta U}
$$

(see notations in Fig. 2).

Charge-discharge cycling was performed with a stepwise increase in $U_{\max }$ value from $1.5 \mathrm{~V}$ to $2.7 \mathrm{~V}$, the steps being of $0.2-0.3 \mathrm{~V}$. The cycling current was changed from $0.5 \mathrm{~A}$ to $4.0 \mathrm{~A}$ with increments of 0.5 A. Eight charge-discharge cycles were performed at each current value followed by averaging the capacitance and resistance values obtained. These stepwise measurements enabled to monitor the changes in capacitance and resistance values with an increase in voltage and current, and thus, to determine the range of stable EDLC performance. As a result, it was found that $2.7 \mathrm{~V}$ may be considered as the maximum working (rated) voltage for all the EDLC prototypes except the 1:1[Y8:GH] one, which demonstrated a steep increase in resistance above $2.3 \mathrm{~V}$ and a decrease in capacitance above $2.5 \mathrm{~V}$. Therefore, for this prototype, the working voltage was chosen as $2.3 \mathrm{~V}$. For all the materials tested, the total number of charge-discharge cycles was at least 500 with no visible deterioration of their characteristics.

For correct comparison of various electrode materials in EDLC prototypes, their specific characteristics will be used. Namely, the gravi- 
metric capacitance (in F/g) or volumetric capacitance (in F/cc) will be referred to the mass of active material in one electrode or to the electrode volume, respectively. The internal resistivity (in $\Omega \cdot \mathrm{cm}^{2}$ ) will be referred to $1 \mathrm{~cm}^{2}$ of visible electrode surface. The values of specific capacitance and internal resistivity thus obtained are listed in Table 3.

As can be seen from Table 3, graphene materials demonstrate rather low capacitance as compared with commercially available Y5, Y8, HC or EC activated carbons even if being mixed with them. Besides, capacitance retention with an increase in current (see the last column in Table 3) is also significantly better in case of activated carbons. This can probably be due to a significant share of graphene oxide in the graphene materials tested. The CB-based electrodes demonstrate better performance that is close to activated carbons. An increase in volumetric capacitance by $14 \%$ (from $57 \mathrm{~F} / \mathrm{cm}^{3}$ to $65 \mathrm{~F} / \mathrm{cm}^{3}$ ) when mixing the Y8 carbon with CB may be accounted for filling in the voids among the Y8 carbon grains of a few micron size with nano-quasi-spherical CB particles that does not result in a significant increase in electrode volume, though increasing the capacitance. Another positive effect of

TABLE 3. Characteristics of EDLC prototypes.

\begin{tabular}{|c|c|c|c|c|c|c|}
\hline $\begin{array}{c}\text { Elec- } \\
\text { trode } \\
\text { material }\end{array}$ & No & $\begin{array}{c}\text { Electrode } \\
\text { composition }^{1}\end{array}$ & $\begin{array}{c}\text { Gravimetric } \\
\text { capacitance, } \\
\mathrm{F} / \mathrm{g}\end{array}$ & $\begin{array}{c}\text { Volumetric } \\
\text { capacitance, } \\
\mathrm{F} / \mathrm{cm}^{3}\end{array}$ & $\begin{array}{l}\text { Resistivity, } \\
\Omega \cdot \mathrm{cm}^{2}\end{array}$ & $\begin{array}{l}\text { Slope, } \\
-d C / d I\end{array}$ \\
\hline \multirow{4}{*}{ 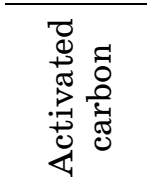 } & 1 & 1:0[Y5:0] & 115 & 71 & 1.08 & 0.06 \\
\hline & 2 & 1:0[Y8:0] & 130 & 57 & 0.85 & 0.04 \\
\hline & 3 & $1: 0[\mathrm{HC}: 0]$ & 112 & 64 & 0.94 & 0.08 \\
\hline & 4 & $1.0[\mathrm{EC}: 0]$ & 104 & 63 & 1.09 & 0.07 \\
\hline \multirow{3}{*}{ 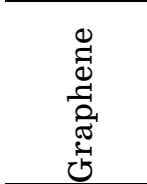 } & 5 & $0: 1[0: x \mathrm{Gn}]$ & 57 & 39 & 1.14 & 0.32 \\
\hline & 6 & $0: 1[0: r G O]$ & 32 & 19 & 1.63 & 0.20 \\
\hline & 7 & $0: 1[0: G Y]$ & 84 & 55 & 0.80 & 0.13 \\
\hline $\begin{array}{c}\text { Carbon } \\
\text { black }\end{array}$ & 8 & $0: 1[0: \mathrm{CB}]$ & 111 & 64 & 0.77 & 0.03 \\
\hline \multirow{7}{*}{  } & 9 & 9:1[Y8:GH] & 123 & 55 & 1.32 & 0.17 \\
\hline & 10 & $1: 1[\mathrm{Y} 8: \mathrm{GH}]$ & 84 & 28 & 3.71 & 0.36 \\
\hline & 11 & $9: 1[\mathrm{HC}: \mathrm{GH}]$ & 113 & 59 & 1.45 & 0.11 \\
\hline & 12 & $9: 1[\mathrm{HC}: x \mathrm{Gn}]$ & 111 & 65 & 0.97 & 0.09 \\
\hline & 13 & $1: 1[\mathrm{HC}: x \mathrm{Gn}]$ & 83 & 56 & 1.13 & 0.19 \\
\hline & 14 & $1: 1[\mathrm{Y} 8: r \mathrm{GO}]$ & 82 & 46 & 0.99 & 0.08 \\
\hline & 15 & 1:1[Y8:CB] & 113 & 65 & 0.73 & 0.07 \\
\hline
\end{tabular}

Note: ${ }^{1}$ The same notations as in Table 2. 
such a combination is a decrease in the internal resistance.

\subsection{Correlation between the electrode surface area and EDLC capacitance}

If the predominant part of electrode nanopores is accessible for the electrolyte, one may expect the electrostatic capacitance to correlate with the surface area of carbon materials used in the electrodes [23, 24]. This hypothesis has been checked for 15 electrode compositions (see those listed in Tables 2 and 3 ) taking into account the material surface area as listed in Table 1 . If the electrode was manufactured from the mixture of two active materials, the total surface area was calculated assuming their additive shares, e.g., for the 9:1[Y8:GH] mixture the surface area was calculated as $0.9 \cdot 2418 \mathrm{~m}^{2} / \mathrm{g}+0.1 \cdot 805 \mathrm{~m}^{2} / \mathrm{g}=2257$ $\mathrm{m}^{2} / \mathrm{g}$. The resulting plots of specific capacitance vs specific surface area are shown in Fig. 3 (gravimetric) and Fig. 4 (volumetric). It is worth noting that we have used the DFT data from Table 1, as they better correlate with the capacitance than BET results, and the 0,0 point (the origin) has also been included as being obvious.

The surface area values in $\mathrm{m}^{2} / \mathrm{cm}^{3}$ in Fig. 4 have been evaluated from the experimentally obtained values in $\mathrm{m}^{2} / \mathrm{g}$, mass of carbon material in the electrode and electrode density as listed in Table 2. In Figures 3 and 4 , diamonds are referred to graphenes or CB, black circles are referred to activated carbons, and hollow circles are referred to mixtures of two active materials. As can be seen from Figs. 3 and 4, the correlation between capacitance $(C)$ and surface area $(S)$ is fairly well with the accuracy of approximation, $\chi^{2}$, being of 0.964 or 0.955 , respectively. Therefore, the $k$ coefficient in equation $C=k S$ describes the capacitance of electric double layer in the EDLC under study comprising various carbon electrodes and acetonitrile-based electrolyte. The values of this coefficient are as follows: $k=0.050 \mathrm{~F} / \mathrm{m}^{2}$ (gravimetric) or $k=0.054 \mathrm{~F} / \mathrm{m}^{2}$ (volumetric) resulting in the mean value of $0.052 \pm 0.002 \mathrm{~F} / \mathrm{m}^{2}$ (or $5.2 \pm 0.2 \mu \mathrm{F} / \mathrm{cm}^{2}$ ) for the capacitance of electric double layer. It should be noted that this value is lower than the value of $0.094 \mathrm{~F} / \mathrm{m}^{2}$ obtained in [18] for 28 porous carbons in similar electrolyte. The difference probably reflects the different origin of carbons studied in [18] and in this work.

In contrast to Figs. 3 and 4 , there is no visible correlation between the capacitance and volume of $\mathrm{CCl}_{4}$ vapour absorbed by the carbon except for the activated carbons of similar origin and pore size distribution with the accuracy of approximation, $\chi^{2}$, exceeding 0.98 (see Fig. 5). This may reflect the fact that the pores larger than $0.63 \mathrm{~nm}$ are not the only factor responsible for the electrostatic capacitance. Morphology of nanostructured materials can probably influence significantly their characteristics (see also Sec. 3.4). 




Fig. 3. Plot of gravimetric capacitance of carbon materials as listed in Tables 2 and 3 vs their specific surface area.

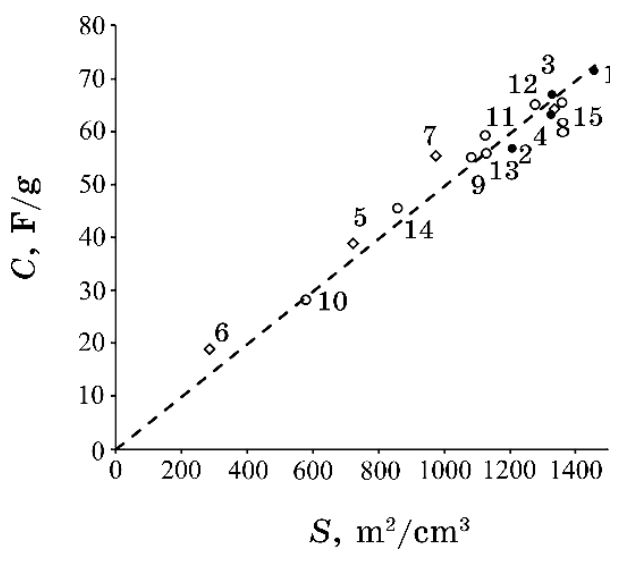

Fig. 4. Plot of volumetric capacitance of carbon materials as listed in Tables 2 and $3 v s$ their surface area referred to the electrode volume.

\subsection{Theoretical capacitance of graphene electrode}

Let us consider the 'ideal' graphene electrode looking like a 'graphene comb' [25], wherein the graphene sheets play the role of a row of teeth in a conventional comb (see Fig. 6). The minimal distance between the adjacent graphene sheets may be assumed to be approximately $1 \mathrm{~nm}[26,27]$, which is sufficient for impregnating the electrode with an organic electrolyte [28]. For such a graphene comb configuration, the contribution from basal planes to the total area (hence, capacitance) is obviously dominant, even if one takes into account that the double-layer capacitance of the edge orienta- 


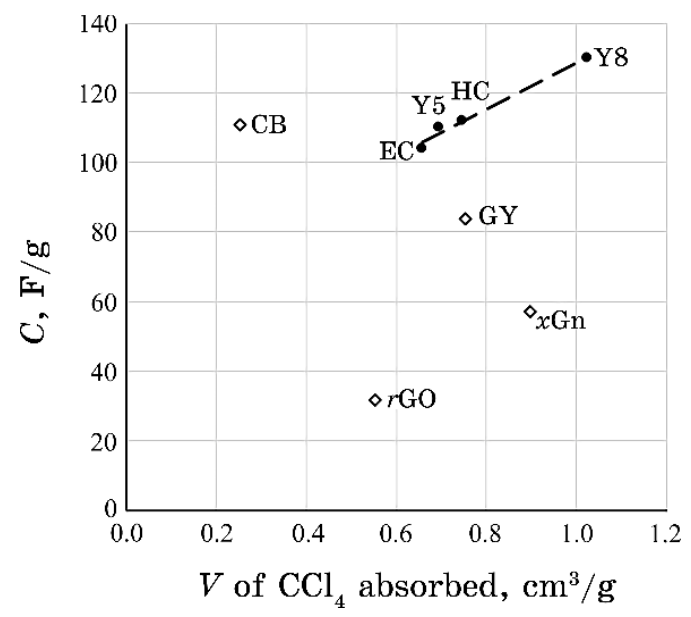

Fig. 5. Plot of capacitance of carbon materials $v s$ the volume of $\mathrm{CCl}_{4}$ absorbed.

tion of graphite was found to be much higher than that of the basal layer [29]. On the other hand, carbons with similar specific surface area but with different morphology and, in particular, higher ratio of edge/basal orientations would reach higher capacitance [30-32], and this fact may probably explain the difference between two values $\left(0.052 \mathrm{~F} / \mathrm{m}^{2}\right.$ or $\left.0.094 \mathrm{~F} / \mathrm{m}^{2}\right)$ mentioned above.

Now, to evaluate the capacitance of a graphene sheet, it is worth noting that approximately a half of its surface area can form the image charge to compensate the charge of ions in the electric double layer [33]. This model agrees in general with experimental results and conclusions made by Kötz et al. [33, 34] who suggested the capacitance saturation might occur in case of very thin carbon walls. Therefore, the maximum used surface area of graphene sheets can hardly exceed $1315 \mathrm{~m}^{2} / \mathrm{g}$. Now, it is easy to show that this results in the specific capacitance values of $69 \mathrm{~F} / \mathrm{g}$ and $52 \mathrm{~F} / \mathrm{cm}^{3}$, if the value of $0.052 \mathrm{~F} / \mathrm{m}^{2}$, as obtained experimentally above, is chosen for electric double layer capacitance. If the value of $0.059 \mathrm{~F} / \mathrm{m}^{2}$, as was obtained in Ref. [34] for the electric double layer capacitance at the graphite basal plane, is cho-

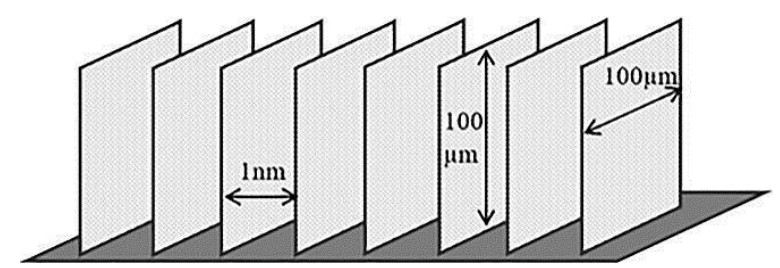

Fig. 6. Graphene electrode modelled as a 'comb' of graphene sheets. 
sen, the specific capacitance can approach the values of $78 \mathrm{~F} / \mathrm{g}$ and 59 $\mathrm{F} / \mathrm{cm}^{3}$. These values agree fairly well with the maximum experimental values of $84 \mathrm{~F} / \mathrm{g}$ and $55 \mathrm{~F} / \mathrm{cm}^{3}$ obtained for GY graphene (see No.7 in Table 3). Other graphene materials tested in this work demonstrate yet lower capacitance and worse capacitance retention with an increase in discharge current (see the last column in Table 3), probably, due to high content of oxygen-containing groups and/or significant aggregation. Higher capacitance of CB electrodes can be accounted for the nanoporous structure of this specialty carbon black material similar to typical activated carbons (e.g., compare the characteristics of $\mathrm{CB}$ and $\mathrm{HC}$ in Tables 1 and 3).

It should be noted that both theoretical and experimental values obtained in this work are significantly lower than maximum theoretical capacitance of $550 \mathrm{~F} / \mathrm{g}$ [35] obtained for ionic liquids (1butyl-3-methylimidazolium hexafluorophosphate) with an assumption that the entire surface of a graphene sheet can accumulate the charge and choosing the electric double layer capacitance as high as $0.21 \mathrm{~F} / \mathrm{m}^{2}$. However, taking into account the data obtained in [21] and in this work, both these assumptions look overestimated. Experimental capacitance values obtained for graphene-based electrodes in organic electrolytes do not normally exceed $100 \mathrm{~F} / \mathrm{g}$ [36], though for additionally activated graphene materials yet larger surface area can be obtained resulting in the capacitance value of 166 F/g [12] or even $220 \mathrm{~F} / \mathrm{g}$ [36].

However, additional activation of graphene can hardly be economically justified and, therefore, we agree with a conclusion made in Ref. [36]: '... the large majority of graphene-like materials cannot yet compete with the cheaper and well-established activated carbons.'.

\section{CONCLUSIONS}

Surface area of graphene materials tested in this work and in some other works is much lower than the theoretical value of $2630 \mathrm{~m}^{2} / \mathrm{g}$ or values reached by the best commercial activated carbons, and the difference can probably be accounted for the significant aggregation of single graphene sheets and/or predominantly mesoporous structure of graphene based materials.

Specific capacitance of graphene-based electrodes and capacitance retention with an increase in current are inferior to the values that can be reached with the best activated carbons specially developed for EDLC application.

Capacitance of electric double layer of graphene, graphenecontaining, and activated carbon materials tested in this work is close to $0.052 \mathrm{~F} / \mathrm{m}^{2}$. 


\section{ACKNOWLEDGMENTS}

Financial support from the National Academy of Science of Ukraine to projects \#8 and \#11 on nanostructured materials for energy storage devices based on supercapacitors is highly acknowledged.

\section{REFERENCES}

1. K. S. Novoselov, V. I. Falko, L. Colombo, P. R. Gellert, M. G. Schwab, and K. Kim, Nature, 490: 192 (2012); https://doi.org/10.1038/nature11458.

2. E. P. Randviir, D. A.C. Brownson, and C. E. Banks, Materials Today, 17: 426 (2014); https://doi.org/10.1016/j.mattod.2014.06.001.

3. X. Zang, Graphene: Fabrication, Characterizations, Properties and Applications (Eds. Hongwei Zhu et al.). Ch. 7. Graphene-Based Flexible Energy Storage Devices (London-Chennai: Academic Press: 2018), p. 175; https://doi.org/10.1016/B978-0-12-812651-6.00007-0.

4. Y. Dong, Z. Wu, W. Ren, H.-M. Cheng, and X. Bao, Science Bulletin, 30: 724 (2017); https://doi.org/10.1016/j.scib.2017.04.010.

5. Y. Yang, C. Han, B. Jiang, J. Iocozzia, C. He, D. Shi, T. Jiang, and Z. Lin, Materials Science and Engineering: R: Reports, 102: 1 (2016); https://doi.org/10.1016/j.mser.2015.12.003.

6. M. Lu, F. Beguin, and E. Fraçkowiak, New Materials for Sustainable Energy and Development. Supercapacitors: Materials, Systems, and Applications (Wiley-VCH: 2013).

7. J. M. Miller, Ultracapacitor Applications, Institution of Engineering and Technology (Stevanage: 2011).

8. B. E. Conway, Electrochemical Supercapacitors: Scientific Fundamentals and Technological Applications (Springer: 2013).

9. O. N. Kalugin, V. V. Chaban, V. V. Loskutov, and O. V. Prezhdo, Nano Lett., 8: 2126 (2008); https://doi.org/10.1021/nl072976g.

10. Y. Maletin, V. Strelko, N.Stryzhakova, S. Zelinskyi, A. B. Rozhenko, D. Gromadsky, V. Volkov, S. Tychina, O. Gozhenko, and D. Drobny, Ener. \& Env. Res., 3: 156 (2013); https://doi.org/10.5539/eer.v3n2p156.

11. A. Peigney, A. Laurent, Ch. E. Flahaut, R. R. Bacsa, and A. Rousset, Carbon, 39: 507 (2001); https://doi.org/10.1016/S0008-6223(00)00155-X.

12. R. Raccichin, A. Varzi, S. Passerini, and B. Scrosati, Natural Materials, 22: 271 (2014); https://doi.org/10.1038/nmat4170.

13. Q. Ke and J. Wang, J. Materiomics, 2: 37 (2016); https://doi.org/10.1016/j.jmat.2016.01.001.

14. J. R. Dahn, T. Zheng, Y. Liu, and J. S. Xue, Science, 270: 590 (1995); https://doi.org/10.1126/science.270.5236.590.

15. O. Vargas, Á. Caballero, and J. Morales, Electrochim. Acta, 130: 551 (2014); https://doi.org/10.1016/j.electacta.2014.03.037.

16. Y.-X. Wang, S.-L. Chou, H.-K. Liu, and S.-X. Dou, Carbon, 57: 202 (2013); https://doi.org/10.1016/j.carbon.2013.01.064.

17. A. García-Gómez, G. Moreno-Fernández, B. Lobato, and T. A. Centeno, Phys. Chem. Chem. Phys., 17: 15687 (2015);

https://doi.org/10.1039/C5CP01904D. 
18. T. A. Centeno, O. Sereda, and F. Stoeckli, Phys. Chem. Chem. Phys., 13: 12403 (2011); https://doi.org/10.1039/C1CP20748B.

19. International Standard IEC 62391-2. Fixed Electric Double-Layer Capacitors for Use in Electronic Equipment (2006).

20. Y. A. Maletin, S. M. Podmogilny, N. G. Stryzhakova, A. A. Mironova, V. V. Danylin, and A. Y. Meletin, Electrochemical Double Layer Capacitor, United States Patent US20080151472A1 (2007).

21. B. Lobato, L. Suarez, L. Guardia, and T. A. Centeno, Carbon, 122: 434 (2017); https://doi.org/10.1016/j.carbon.2017.06.083.

22. T. A. Centeno and F. Stoeckli, Carbon, 48: 2478 (2010); https://doi.org/10.1016/j.carbon.2010.03.020.

23. N. Jäcke, M. Rodner, A. Schreiber, J. Jeongwook, M. Zeiger, M. Aslan, D. Weingarth, and V. Presser, J. Power Sources, 326: 660 (2016); https://doi.org/10.1016/j.jpowsour.2016.03.015.

24. F. Stoeckli and T. A. Centeno, J. Mater. Chem. A, 1: 6865 (2013); https://doi.org/10.1039/C3TA10906B.

25. J. J. Yoo, K. Balakrishnan, J. Huang, V. Meunier, B. G. Sumpter, A. Srivastava, M. Conway, A. L. M. Reddy, J. Yu, R. Vajtai, and P. M. Ajayan, Nano Lett., 11: 1423 (2011); https://doi.org/10.1021/nl200225j.

26. N. Jäckel, P. Simon, Y. Gogotsi, and V. Presser, ACS Energy Lett., 1: 1262 (2016); https://doi.org/10.1021/acsenergylett.6b00516.

27. J. Chmiola, G. Yushin, Y. Gogotsi, C. Portet, P. Simon, and P. L. Taberna, Science, 313: 1760 (2006); https://doi.org/10.1126/science.1132195.

28. M. Nakamura, N. Sato, N. Hoshi, and O. Sakata, Chem. Phys. Chem., 12: 1430 (2011); https://doi.org/10.1002/cphc.201100011.

29. J.-P. Randin and E. Yeager, J. Elec. Chem. \& Inter. Electrochem., 36: 257 (1972); https://doi.org/10.1016/S0022-0728(72)80249-3.

30. J.-P. Randin and E. Yeager, J. Elec. Chem. \& Inter. Electrochem., 58: 313 (1975); https://doi.org/10.1016/S0022-0728(75)80089-1.

31. T. Kim, S. Lim, K. Kwon, S.-H. Hong, W. Qiao, C. K. Rhee, S.-H. Yoon, and I. Mochida, Langmuir, 22: 9086 (2006); https://doi.org/10.1021/la061380q.

32. D. Qu, J. Power Sources, 109: 403 (2002); https://doi.org/10.1016/S03787753(02)00108-8.

33. Y. Maletin, N. Stryzhakova, S. Zelinskyi, S. Chernukhin, D. Tretyakov, and S. Tychina, Int. J. Sc. \& Eng. Inv., 7: 146 (2018); http://www.ijsei.com/papers/ijsei-77918-24.pdf.

34. M. Hahn, M. Baertschi, O. Barbieri, J.-C. Sauter, R. Kotz, and R. Gallay, Electrochemical and Solid-State Lett., 7: A33 (2004); https://doi.org/10.1149/1.1635671.

35. Ji Chen, Chun Li, and Gaoquan Shi, J. Phys. Chem. Lett., 4: 1244 (2013); https://doi.org/10.1021/jz400160k.

36. Y. Huang, J. Liang, and Y. Chen, Small, 8: 1 (2012); https://doi.org/10.1002/smll.201102635. 